\title{
Juventude, política e consumo: imagens juvenis na publicidade brasileira a partir de 1964
}

\author{
Maria Eduarda da Mota Rocha*
}

Resumo: No Brasil, desde a década de 1960, a assimilação da juventude pela publicidade deu-se em duas frentes. Por um lado, jovens influenciados pelas contraculturas e pelo clima de mobilização política foram incorporados à indústria da publicidade para trabalhar com pesquisa e criação. Por outro lado, nos anúncios, os jovens passaram a encarnar uma promessa de felicidade perfeitamente integrada à sociedade capitalista. Este artigo trata desse duplo processo a partir da análise de revistas do meio publicitário e de anúncios publicados na revista Veja, entre 1968 e 2001.

Palavras-chave: Publicidade, juventude, ética romântica

\begin{abstract}
In Brazil, since the 1960's, the assimilation of youth by advertising has occurred in two different ways. In one hand, the advertising industry absorbed young people affected by the counterculture and by the political mobilization of that period as professionals in the areas of arts and research. In the other hand, in the ads, young people became the icons of happiness, perfectly integrated to the capitalistic society. This article intends to interpret both processes based upon de magazines of the advertising industry and the ads published in Veja magazine between 1968 and 2001.
\end{abstract}

Keyword: Advertising, youth, ethics romantic

\footnotetext{
* Professora do Programa de Pós-Graduação em Sociologia da UFPE. Autora de $O$ consumo precário - pobreza e cultura de consumo em São Miguel dos Milagres. Maceió: Edufal, 2002, e de A nova retórica do capital: a publicidade brasileira em tempos neoliberais. São Paulo: Edusp, 2010.
}

Latitude, vol. 4, nº 1, pp. 09-23, 2010

DOI: https://doi.org/10.28998/2179-5428.20100102 
Juventude, política e consumo: imagens juvenis na publicidade brasileira a partir de 1964

\section{I - Ética romântica e juventude}

A valorização da "juventude" em detrimento da "velhice" é típica em sociedades modernas, em que a "tradição" é deslocada pela "novidade" e as energias humanas parecem estar mais voltadas para as promessas do futuro do que para o legado do passado. O jovem, como encarnação do novo, parece estar mais apto a ser socializado segundo os hábitos, técnicas e conhecimentos que o desenvolvimento das forças produtivas e os processos de racionalização cultural não cessam de criar.

Entretanto, até o romantismo, a centralidade do jovem na moderna cultura ocidental ainda carecia de uma justificação moral e de uma matriz estética. Não por acaso, o romantismo também foi a matriz cultural que consolidou o modo de consumo moderno, chamado por Collin Campbell de "hedonismo imaginativo" ou "auto-ilusório". Esse autor mostra como uma ética que justifica moralmente o consumo foi formada entre as classes médias inglesas no século XVIII, a partir do próprio protestantismo. Não cabe aqui retomar o seu longo percurso argumentativo, mas apenas assinalar que as raízes do hedonismo moderno podem ser localizadas no pietismo, no deísmo sentimental, no sentimentalismo e, finalmente, na ética romântica. Isso porque, cada um deles a sua maneira, estimulou e justificou moralmente o controle das emoções que, uma vez manipuladas com o propósito de obtenção de prazer, caracterizam o modo de consumo moderno. A sua marca maior seria o "sonhar acordado" (day dreaming), a atividade mental na qual vívidas imagens são trazidas à mente ou elaboradas para, em seguida, serem exploradas no intuito de maximizar o prazer (Campbell, 1987: 82).

A prática do "sonhar acordado" expressava o desgosto romântico com a vida ordinária e a desilusão com a modernização, que levavam os artistas a eleger, como inimigos, o utilitarismo e o racionalismo de uma sociedade que havia se tornado "o reino de forças econômicas frias e impessoais" (Campbell, 1987: 179). Vale salientar que o interesse, tanto para Campbell como neste trabalho, não reside no movimento estético circunscrito aos séculos XVIII e XIX, e sim numa "ética romântica" que conformou uma matriz cultural de amplo alcance nas sociedades ocidentais, desde então. Esteve presente, por exemplo, entre boêmios, modernistas, beats e hippies. Hoje, é central em muitos anúncios da publicidade brasileira (Rocha, 2010), em que o jovem aparece como a encarnação mais perfeita da figura do hedonista, já com certa autonomia comparativamente às crianças, mas ainda liberto das obrigações conjugais, parentais, laborais que pesam sobre o pai e a mãe de família.

Ainda assim, a compreensão dos usos que a publicidade brasileira faz de figuras juvenis exige que passemos desse nível de generalidade, em que pesa a centralidade da juventude para a cultura e o consumo modernos desde o romantismo, até a consolidação do capitalismo monopolista no Brasil, a partir dos anos 1950, e os processos políticos que lhe deram direções discrepantes antes e depois de 1964. Não se trata de apontar o apelo "natural" das imagens de juventude nos anúncios, mas de mostrar como esse apelo cresce e muda de significado com a adesão da publicidade brasileira a um ethos hedonista a partir 
da segunda metade do século $X X$, ethos este correlato ao aumento vertiginoso da produção industrial e ao sufocamento dos valores políticos progressistas após o Golpe de 1964.

Avançando nessa direção, esse artigo analisa a assimilação da "juventude" pela publicidade brasileira em um movimento simultâneo e coordenado que contemplou, por um lado, a acomodação das pretensões libertárias dos próprios jovens publicitários no interior da indústria e, por outro lado, a ressignificação dessas pretensões em figuras juvenis que representam, nos anúncios, a ruptura com a vida sóbria do trabalho e do cotidiano rotinizado, em vez de um questionamento mais amplo da ordem política, econômica e social.

\section{II - "Liberdade é uma calça velha, azul e desbotada"}

Este slogan já foi usado para vender um jeans famoso e para dar título ao trabalho de Anna Figueiredo sobre a disseminação de um ethos hedonista na publicidade brasileira, mesmo antes do Golpe de 1964 (Figueiredo, 1998). Aqui, interessa-me mostrar o paralelo entre a assimilação de modelos de comportamento juvenis pela publicidade e a assimilação das pretensões libertárias dos próprios jovens publicitários pela indústria.

Os publicitários, especialmente os profissionais de criação e de pesquisa, eram, muitas vezes, jovens que haviam sido marcados pelo clima de mobilização política que antecedeu o Golpe e, mesmo ingressos na indústria da publicidade, não escapavam da influência das contraculturas dos anos 1960. Muitos tinham pendores progressistas, fossem eles definidos à moda classista ou contracultural, ou por uma combinação entre ambos. Vejamos, a esse respeito, a disputa travada pelos jovens publicitários, muitos dos quais oriundos das universidades e dos circuitos de produção cultural independente, contra os limites que o governo militar tentava impor à publicidade em nome da "moral e dos bons costumes" (Rocha, 2010).

A afinidade com o Regime Militar demonstrada por empresários do publicitário setor não era endossada pelos trabalhadores mais qualificados das agências: os profissionais de criação e os especialistas em pesquisa. Estes últimos eram recrutados entre os egressos das faculdades de ciências humanas, especialmente as de sociologia. Foi o caso de profissionais que ainda chefiam departamentos e consultorias de planejamento e pesquisa, como Clarice Herzog, Célia Belém e Jaime Troiano. A crise de consciência era aplacada pela falta de opção acadêmica nos anos de Ditadura e pela visão da publicidade como uma ocupação passageira. "Eu, mexer nessa sujeira? Deveria ser professor e pensar na sociedade", dizia Troiano, que, em 1978, assinou com outros sociólogos o manifesto "Publicitários pela Anistia" (Propaganda, n” 558, dez./97).

O caráter conservador e capitalista da atividade publicitária associada ao Regime Militar também incomodava os profissionais de criação, em sua maioria, 
Juventude, política e consumo: imagens juvenis na publicidade brasileira a partir de 1964

de esquerda ${ }^{1}$. Em 1968, Geraldo Alonso, empresário conservador, contratou para a Norton um grupo de criativos autodenominados de "os subversivos", que, até 1978, usaram a publicidade para protestar contra a falta de liberdade de opinião. O mais marcante destes protestos foi a série de anúncios para a gráfica Repro, veiculada entre 1969 e 1979. Em cartões de natal, a figura de Cristo aparecia a cada ano sob uma nova sentença: "Procurado...", ou "não esqueçam que o menino que está nascendo agora vai ser barbudinho, cabeludo e vai mudar tudo". A ousadia estava em arrancar Cristo do registro conservador e retratá-lo como um libertário. De pouco servia a agência ensaiar uma explicação para o nome incômodo do grupo, dizendo que teria surgido "para revolucionar a criação publicitária" (Anuário de Propaganda, 1969). Isto porque o primado da inovação criativa, naquele momento, era indissociável do protesto não só contra as formas correntes do discurso publicitário, mas sobretudo contra os valores cristãos conservadores apregoados pela propaganda do Regime e em nome dos quais a censura era praticada.

A década de 60 foi sacudida pelos movimentos contraculturais e seus valores libertários e isso foi usado como recurso estratégico por agências que se contrapunham às estabelecidas. Nos Estados Unidos, matriz da publicidade mundial, acontecia o que se convencionou chamar de "revolução criativa" provocada pelas "boutiques criativas", agências até então sem muita tradição cujo diferencial eram a inventividade e a ousadia, à maneira da DDB, de William Bernbach e da Wieden\&Kennedy, fundada por dois ex-beatnicks para "levar a contracultura à publicidade" (Klein, 2002: 329). No Brasil, a DPZ já surgiu inspirada nessa tendência, à qual a Norton aderiu ao contratar os "suversivos" e fazer deles o seu cartão-de-visitas. No Anuário de 1971, outros tentavam neutralizar este discurso, acusando as "criativas" de falta de compromisso com o negócio dos clientes. A Thompson, que até os anos 60 liderava o mercado e se promovia como uma agência de especialistas, "finalmente revela o que ela é capaz de criar", apoiando-se no sucesso do anúncio do Chantilly Royal, que não agradou aos "publicitários", mas resultou em grande aumento de vendas. Outro anúncio do mesmo Anuário se contrapunha explicitamente à Norton: "Quando alguém diz que um anúncio tem que ser antes de tudo criativo, esse alguém está subvertendo uma verdade: antes de tudo, um anúncio tem de comunicar. E comunicar para vender. Agora, se você quiser aceitar os argumentos dos subversivos, o problema é seu. Mas não se queixe quando o seu produto for cassado do mercado. Promark Propaganda e Marketing". A disputa entre as agências dominantes e as recémchegadas assumia, assim, a forma de uma oposição entre conservadores e libertários, sendo os jovens pesquisadores e profissionais de criação associados a estes últimos.

Apesar das contestações, no discurso interno ao campo publicitário, a ousadia e a criatividade despontaram como recursos indispensáveis para o

${ }^{1}$ Em sua coluna na revista Propaganda, Armando Ferrentini dá um testemunho sobre o período em que constata os arroubos esquerdistas dos profissionais de criação. Propaganda, n $^{\circ}$ 589, jun./00, p. 99. 
Maria Eduarda da Mota Rocha

prestígio das agências no final da década de 60, indicando o movimento de translação pelo qual passava a publicidade brasileira, ao menos parcialmente. A julgar pelo primeiro Anuário de Propaganda, de 1969, o atestado de liberdade criativa era obtido mediante a oposição explícita aos valores cristãos de matiz conservador, justamente aqueles em cuja defesa se empenhava Octávio Costa, em seu esforço para enquadrar o discurso publicitário em nome do Regime Militar (Fico, 1997). Impressiona a predominância de um mesmo recurso nos anúncios das agências: o uso deslocado de máximas cristãs, como "junta-te aos bons e serás um deles", da Standard, referindo-se aos seus 133 clientes satisfeitos. Mais uma vez, foi uma agência pequena quem formulou de modo mais extremo esta estratégia de autopromoção: “Deus que nos perdoe. Pecar é humano. E nós pecamos. Todo santo dia. Para sermos ainda mais francos, somos pecadores profissionais. Quando temos de anunciar um produto feminino - é impossível não cogitar da mulher do próximo. E nem sempre podemos guardar castidade, pois muitas vezes o apelo erótico é valido. E, ainda por cima, inserido no contexto do mercado. Ah, nós pecadores cobiçamos desesperadamente as coisas alheias. Quando, por exemplo, uma fatia de mercado ainda está nas mãos da concorrência de um cliente nosso. Valha-nos Deus na hora de nossa morte, mas dos 7 pecados capitais só da preguiça e da mentira não somos culpados. Nossos clientes são nossas testemunhas. Agora e no juízo final. E você, anunciante que nos lê, porque não entra na nossa irmandade? Amém. Marcus Pereira Publicidade".

A possibilidade de autopromoção das agências como "criativas" resultou em um maior prestígio para os profissionais desta área, alimentando suas pretensões artísticas e seus ímpetos oposicionistas. No I Encontro de Criação, realizado como parte do III Congresso de Propaganda, em 1978, Roberto Duailib surpreendeu-se ao constatar que "ao invés dos supostos profissionais alienados, revelou-se profissionais preocupados com a função social de seu trabalho e com a organização de seus interesses comuns" (Propaganda n² 261, abr./78). O que Eloy Simões tachou de um encontro político pareceu, ao olhar de um observador externo e sarcástico como Ziraldo, uma "psicoterapia de grupo", pois evidenciava o quanto a subordinação de sua criatividade ao mercado angustiava os criadores (Propaganda $\mathrm{n}^{\circ}$ 261, abr./78). "Somos empregados do sistema. E, que eu saiba, ninguém deixa a consciência no cabide na hora de ir trabalhar", diria Neil Ferreira no II Encontro Nacional de Criação, realizado um ano depois. Na mesma ocasião, Ricardo Guimarães constatou que "o verdadeiro tema do encontro é a divisão do homem de criação entre a sua teoria social e política e a sua prática profissional. Um assunto velho, chato... e, parece, até hoje não resolvido" (Meio e Mensagem, n 28, ago/79).

O III Congresso e o II Encontro de Criação foram palcos de acalorados debates sobre a função social da propaganda e a posição política dos publicitários, questões quase sempre levantadas pelos profissionais de criação. A publicidade ainda não havia passado "da visão romântica" ao pragmatismo da década de 90 . Em 1979, Duda Mendonça, em carta aberta na qual cobrava um comportamento ético a Roberto Duailib, afirmava ter largado negócios mais rentáveis para se dedicar a "aventura" da propaganda, essa "coisa de hippie" que só valia a pena porque tinha também "funções sociais, políticas e culturais" (Propaganda, n² 263, 
Juventude, política e consumo: imagens juvenis na publicidade brasileira a partir de 1964

jun/78). Assim, através dos profissionais de criação, a efervescência política das décadas de 60 e 70 adentrava o campo publicitário. Os criativos inspiravam-se em outros grupos cuja produção cultural expressava uma esperança de mudança da sociedade brasileira, grupos esses cujos membros tinham uma trajetória social semelhante a deles: indivíduos de classe média urbana produzindo para um público também urbano de classe média (Ortiz, 1988: 102). José Mário Ortiz Ramos mostra como a publicidade foi refúgio de profissionais que não encontravam condições favoráveis para a realização de suas capacidades criativas em outros setores, como o cinema, por exemplo (Ramos, 1990).

A percepção inflada de sua própria autonomia dentro do negócio da propaganda por parte dos "criativos" deveu-se, sobretudo, a uma conjuntura de rearranjo do campo publicitário nacional e de valorização da ousadia como estratégia de autopromoção das agências, sob forte influência da matriz norteamericana e sob a proteção do Regime Militar. A este respeito, José Carlos Durand também menciona o surgimento de premiações e a crescente visibilidade dos profissionais de propaganda entre os fatores que até hoje alimentam o "fascínio da publicidade como domínio de "criação'" (Durand, s./d.: 6). Some-se a isto, no período em questão, a autonomia circunstancial que dava aos criativos outras razões para pensar que, através de sua atividade, poderiam fazer valer suas posições políticas tendencialmente antagônicas ao "sistema". Só assim é possível explicar a visão da publicidade como "coisa de hippie", que desapareceu com o avanço da racionalização e da cobrança por resultados pelos anunciantes, no final dos anos 80. Na verdade, o "culto excessivo da criatividade", o "excesso de uma criação de barba, cabelo comprido e iê-iê-iê" foi criticado desde o seu surgimento, em contraposição a uma propaganda eficiente, como exemplificado nessas palavras de John Straiton, da Ogilvy \& Mather do Canadá, publicadas na revista Propaganda ( $\mathrm{n}^{\circ} 166$, mar./70).

Os pudores cristãos ligados ao sexo e às relações familiares eram os principais tabus questionados, embora esse questionamento provocasse reação, não apenas do Governo Militar, mas de autoridades do próprio setor publicitário. Em 1973, Fernando Almada, um dos principais criativos dos anos 70, criticou um anúncio da Fotoptica que dizia: "O melhor presente que você pode dar para o seu filho é parar de encher o saquinho dele". Segundo o publicitário, além da linguagem inapropriada, o anúncio pecava também na representação da relação entre pai e filho, em que o respeito ao primeiro era desencorajado (Propaganda, $\mathrm{n}^{\circ}$ 207, out./73). Apesar de enfrentar alguma resistência no interior do próprio campo publicitário, a liberação sexual e o questionamento da autoridade patriarcal estavam muito ao gosto do período. Mas a crítica tendia a se converter em simples reivindicação por mais liberdade criativa, ostentada no distanciamento em relação aos pudores cristãos. Do lado do Regime, apesar dos protestos em nome dos bons costumes, a "tradição" e a "família" mostraram-se menos importantes do que a "propriedade". E, neste ponto, o discurso publicitário era totalmente convergente ao dos setores conservadores da sociedade brasileira, ainda que não se possa subestimar o papel dos jovens profissionais de criação e pesquisa como focos de resistência no interior do setor. 
Sendo assim, no tocante ao estatuto da criação na produção publicitária, a especificidade da década de 70 estava nas implicações políticas da defesa da autonomia criativa por profissionais 'esquerdistas'. Ela se desdobrava numa crítica ao cerceamento da liberdade de expressão, quer fosse feito em nome da eficácia da publicidade, quer em defesa do conservadorismo cristão. Eis a principal fonte de conflito entre o Regime Militar e o campo publicitário. Por sua causa, foi um senador do partido governista que, em 1978, conseguiu aprovação do Senado para um projeto que propunha limitar a atividade publicitária, tornando definitiva a pré-censura dos anúncios, restringindo a publicidade de medicamentos e de outros bens de consumo, e exigindo a referência ao certificado de inspeção e às fórmulas de composição dos produtos dos ramos de alimentos, higiene e limpeza. A revista Meio e Mensagem registrou a "repulsa geral ao projeto" n 40/72, do senador José Lindoso, da Arena do Amazonas, e a defesa da lei 4680 como o instrumento de regulamentação do setor (Meio e Mensagem, $\mathrm{n}^{\circ}$ 8, ago./ 78). Já no espírito da abertura do final da década, chegou ao ponto de perguntar "até quando os reacionários deste país vão querer enquadrar tudo na 'segurança nacional'?" (Meio e Mensagem, $\mathrm{n}^{\circ} 11$, out./78). E, como era de se esperar, veio dos criadores a manifestação mais extrema de repúdio ao projeto. Ironizando o caráter autoritário do Regime, o Clube de Criação de São Paulo publicou anúncio feito pela DPZ em que "saúda o presidente Figueiredo por ter sido eleito ontem", aludindo à eleição de Luiz Celso Piratininga Figueiredo para a presidência da Associação Paulista da Propaganda. E prometia "apoio para fazer o projeto Lindoso cair do cavalo" (Meio e Mensagem, $\mathrm{n}^{\circ} 12$, nov./78).

A acidez desses protestos destoa das concessões feitas às pressões do executivo federal. $\mathrm{O}$ medo da regulamentação externa há muito era o elemento agregador do campo publicitário. Já no I Congresso de Propaganda, em 1957, os agentes marcaram posição contra a intervenção do governo (Propaganda, $\mathrm{n}^{\circ} 24$, fev./58). Mas, somente em abril de 78, o código de auto-regulamentação foi aprovado, sob a ameaça do projeto Lindoso. Desde 1969, os anúncios sofriam censura prévia, o que o Senador propunha institucionalizar de modo definitivo. O código sinalizou para o governo a disposição do campo em coibir internamente os "abusos", entendidos como referências ao sexo, à violência, ao conflito. Contentando-se com este instrumento, o Regime suspendeu a censura prévia aos comerciais de rádio e TV, ainda em 1978 (Meio e Mensagem, $\mathrm{n}^{\circ}$ 13, dez./78). A $\mathrm{ABAP}$, que havia feito lobby em Brasília, comemorou este "voto de confiança à publicidade (que) traz esperança de que o governo federal não apóie o projeto Lindoso em tramitação" (Meio e Mensagem, n' 13, dez./78) na Câmara. De fato, o governo acabou por barrar o projeto. Foi este o contexto de surgimento do CONAR, como instrumento de auto-regulamentação das atividades publicitárias com base no código, e contra a iniciativa governamental. Apesar de responder imediatamente à tentativa de regulamentação por parte do governo autoritário, o CONAR, implementado efetivamente em 1980, na verdade tem também como causa a democratização por que passava a sociedade brasileira desde o final da década de 70. Parte integrante deste processo, a crescente visibilidade da defesa dos direitos do consumidor e a criação de órgãos municipais e estaduais dedicados ao tema incomodavam particularmente o setor porque, desde o início dos anos 70, 
Juventude, política e consumo: imagens juvenis na publicidade brasileira a partir de 1964

esta questão costumava aparecer na cena pública vinculada a reivindicações pela restrição da publicidade (Taschner, s./d.: 62-64). A auto-regulamentação, mais retórica do que qualquer outra coisa, foi a resposta do campo a essa dupla ameaça, do governo autoritário e de uma sociedade civil mais mobilizada.

No plano dos anúncios, os anseios de liberdade que a figura do jovem passava a encarnar convergiam para a consolidação do consumo como o âmbito natural de seu exercício, o que não parece restrito ao caso brasileiro. A ressignificação de experiências, símbolos e matrizes culturais dos movimentos juvenis da década de 1960 pela indústria da publicidade foi registrada, por exemplo, também nos Estados Unidos (Silvulka, 1998). No Brasil, tratou-se mesmo de uma reconstrução positiva da imagem de uma geração que, até então, para muitos, era sinônimo de ameaça à ordem social e aos bons costumes (Abramo, 1997: 31). Mas, de significado cultural mais abrangente foi a transformação gradual da juventude em um signo publicitário preferencial, quando os seus pendores de contestação passaram a ser assimilados por uma versão consumista do hedonismo, em decorrência de uma transformação global da sociedade, a começar pela mudança da estrutura produtiva e dos padrões de consumo que deram sustentação ao incremento técnico, financeiro e discursivo da própria publicidade. Isso está na raiz da consolidação da indústria da publicidade, que lhe permitiu incorporar aqueles jovens profissionais. Além disso, convém considerar também o silenciamento de atores políticos contestadores e a gradativa substituição dos circuitos independentes de produção e consumo pela indústria cultural, o que demandou a profissionalização do artista e do intelectual em níveis antes desconhecidos, delimitando as condições para as estratégias de reconversão social que encaminhou muitos daqueles jovens ao setor publicitário.

Um anúncio de 1968 dirigido especificamente a profissionais da publicidade, em uma revista do meio, ilustra a maneira como eventuais crises de consciência poderiam ser tratadas, no novo contexto. Ele ironizava os rebeldes do período e aderia sem reservas ao consumo como a razão maior da existência. O cenário era um pátio diante de uma mansão, onde pessoas elegantemente vestidas observavam um homem jovem junto a seu carro. "Eles riram quando eu lhes contei meu salário. Mas quando entrei no meu Galaxie!". Outros dois homens comentam: "Será que ele é mesmo tão importante e ganha tanto dinheiro? Claro, olha ele entrando no Galaxie.". O arremate é explícito: "Com talento e com trabalho, você é hoje um publicitário importante... Com o Galaxie, você vai botar a cabeça acima da multidão. Vai sair da rotina. Vai agradar mais do que entendido em Marcuse em festa de barbudinho" (Propaganda, n 149, out./68). A desqualificação da barba e de um dos teóricos mais influentes nos movimentos juvenis dos anos 60 tenta promover um modelo de jovem bem-sucedido profissional e financeiramente, em detrimento de um modelo "alternativo", de juventude contestadora ligada às contraculturas. Essa disputa se prolonga até hoje, e o discurso publicitário tende a oscilar entre a representação do jovem como sinônimo de liberdade, correndo numa trilha paralela à vida ordinária do trabalho e das obrigações familiares, e a representação do consumidor ideal como jovem, integrado à vida ordinária sem perder o viço da juventude. É o que veremos a seguir. 


\section{III - A convergência entre as figuras do "jovem" e do "consumidor ideal"}

Nos anúncios, a década de 1960 parece marcar o declínio da representação então corrente do consumidor como o pai de família compenetrado e o momento a partir do qual a juventude passou a ser um "conceito" cada vez mais associado aos produtos, na publicidade brasileira de ponta. Uma peça do Ford Corcel do começo dos anos 1970 ilustra essa situação. Quatro pessoas estão de pé ao lado de quatro carros, todos do mesmo modelo. Sob a foto, lê-se: "Estamos do lado dele. Eu estou do lado dele. É jovem, eu sinto isso. Eu... Valeu o dinheiro. Eu... Me sinto segura, ele transmite força. Eu... No Corcel, a gente sente que está dirigindo... Eu mudei, estou mais novo. Deve ser o carro - declarou um homem de meia idade, bem vestido e sorridente... Timidamente, a jovem dona de casa externou sua opinião - a gente é mais respeitada aqui dentro. Insistimos - bom, ele deixa a gente mais bonita. E não dá problema... Ford Corcel. O carro jovem" (Anuário de Propaganda, 1971). O slogan apenas explicita uma centralidade da classificação etária que transparece ao longo de todo o texto do anúncio, e a positividade associada à juventude em detrimento da maturidade, o que fica evidente nos trechos grifados.

Na década de 1980, o apelo à juventude já se espraiava pelo conjunto do discurso publicitário, abrangendo diferentes ramos e produtos, muitos dos quais, estiveram associados desde cedo a um modo de vida juvenil, como os esportes e as motocicletas. Nos anúncios que adotavam tal estratégia, o jovem aparecia como o indivíduo livre para usufruir a "emoção de viver", como sugeria a Honda (Veja, 20/06/84). O esporte e a aventura despontavam como fontes de prazer e como exercício de liberdade. Roupas e calçados especialmente dedicados a estas atividades encontravam nelas mesmas o seu principal apoio promocional. A Nike vendia "a vida na sua melhor forma" e a Topper, o próprio esporte a que se dedicava, o "walking" (Veja, 20/06/84). A marca de roupas Tucano contava a história de "um cara chamado aventura", fotografado no topo de uma montanha, o tipo de gente "que corre atrás dos sonhos com tração 4 rodas. Porque vai ver a vida é mesmo essa aventura que o Kiko, tão obstinadamente, procura pelos 4 cantos do mundo" (Veja, 19/08/87). Nesses anúncios, a juventude representava a possibilidade ou o desejo de libertação de uma vida ordinária, associada às obrigações cotidianas que o adulto tem mais dificuldade de evitar.

Mas tais apelos à liberdade ainda conviviam com outro tipo de anúncio também pautado na "juventude", nos quais ela se combinava ao prestígio para promover o produto. O Monza Hatch mostrava-se como "um esporte para quem conquistou o seu espaço" (Veja, 20/03/85). A Marlboro, ao divulgar sua equipe de motociclismo, não esquecia de lembrar que era "o número 1 no mundo" (Veja, 23/09/87). O Hobby, versão esportiva do Corcel II, retratava um tenista e um veleiro, para não deixar dúvidas sobre o tipo de 'esportista' que estava em foco (Veja, 13/02/80). Nestes casos, a "juventude" era uma maneira nova de retratar o "prestígio", o que fica evidente na famosa série de anúncios que a agência DPZ fez para os cigarros Hollywood, em que "o sucesso" traduzia-se na prática de esportes radicais, como um salto de pára-pente sobre as dunas da Namíbia (Veja, 19/10/83). Ser bem-sucedido equivalia, então, a ter tempo e dinheiro para escapar da vida ordinária, como sugerido em anúncio dos cigarros John Player Special (Veja, 
Juventude, política e consumo: imagens juvenis na publicidade brasileira a partir de 1964

10/03/82). Assim, em muitas peças publicitárias, o apelo à "juventude" tinha seu caráter libertário acomodado ao recurso do status.

Entretanto, havia casos em que este apelo redundava em uma crítica às convenções do "paletó e gravata", tal como no comercial da Hering em que jovens sentados à mesa de uma sala de reuniões usavam cortes de cabelo extravagantes $\mathrm{e}$ camisetas de malha, anunciando solenemente um novo tempo de direito à diferença e de recusa da formalidade: "os anos 90 vêm aí. De camiseta Hering". O texto complementar é ainda mais contundente: "Desculpa, tio. Mas a idéia é fazer tudo diferente. A gente aprendeu muito com vocês, pode crer. Mas algumas coisas precisam mudar e o senhor sabe disso. No dia em que a gente estiver aí no seu lugar, ninguém mais vai trabalhar feito um louco, todo engravatado, sem tempo para curtir a vida e os filhos que a gente quer ter. Dinheiro é bom. Mas só quando traz felicidade. A gente quer mais é vestir uma camiseta e ficar livre e solto para ser até um homem sério na hora que precisar. Desculpa, tio. Mas o sonho não acabou" (Veja, 12/04/89). A referência direta aos movimentos contraculturais aparece nessa última frase e, no conjunto do anúncio, a juventude reivindica a condição de portadora dos valores românticos da liberdade e da autenticidade. Para os que podem pensar ser essa a tônica das marcas de roupas juvenis, lembro que, ainda nos anos 80, a Wrangler e a US Top apelavam para o prestígio em seus anúncios, a última, inclusive, com a célebre campanha do "bonita camisa, Fernandinho", cujo slogan resumia: "o mundo trata melhor quem se veste bem" (Veja, 30/05/84 e 27/06/84, respectivamente)

O anúncio da Hering sinaliza a presença de uma imagem romântica da juventude na publicidade, em detrimento de uma visão utilitária de ser humano. De acordo com essa imagem, a liberdade juvenil pode ser vista como uma resistência à massificação, uma vez que a juventude aparece como a idade da busca pela diferença e pela individualização. Duvido que outra marca tenha sido tão feliz nessa associação quanto a dos cigarros Free. Lançado como uma marca de baixos teores, o Free apresentava-se nos anos 80 como "uma simples questão de bom senso" (Veja, 30/01/85). Uma mulher jovem de tênis, muito à vontade em uma varanda, garantia: "nós temos alguma coisa em comum". O apelo ao "bom senso" voltou no final da década de 90 para divulgar a diminuição ainda maior dos teores de nicotina e alcatrão do produto (Veja, 15/01/97).

Nos anos 90, a suavidade diferenciada de Free deu lugar à "liberdade", como conceito central de seus anúncios. A marca passou a encarnar uma atitude que assumiu o centro das peças publicitárias. Uma delas dizia: "Liberdade. Nunca me tire esse gosto da boca. Se tentar, eu mordo". O slogan "cada um na sua, mas com alguma coisa em comum" (Veja, 28/02/96) atiçava um senso de individualidade, ao mesmo tempo em que não descartava o espírito de grupo atribuído aos jovens, já presente no anúncio da década de 80 . A novidade, agora, é uma aguçada carência de individualidade expresso no "cada um na sua". Nos anúncios, ela assumia a forma da história de diferentes "personagens", todos jovens e "autênticos". Em 1999, um deles dizia: "minha cabeça está aberta 24 horas por dia. Para grandes saques e depósitos interessantes" (Veja, 24/03/99).

Em 2000, a campanha apresentava seus protagonistas com uma pequena ficha onde se lia o seu gênero, idade e profissão, quase todos jovens e ocupados no 
domínio da arte, como cenógrafo, coreógrafa, diretora de arte, artista plástico e fotógrafo. Campbell assinalou que a juventude e a arte convergem para os valores românticos, dentre os quais, a "individualidade genuína", representada pela figura do poeta maudit, que se recusava a ceder às pressões sociais em nome do cultivo do self. Vejamos, então, as respostas destes protagonistas à questão "qual é a sua?", para delas extrair os conceitos mais específicos a cada anúncio. No primeiro deles, uma coreógrafa tatuada e de ponta a cabeça dizia: "a melhor parte da minha vida é o improviso" (Veja, 26/07/00). Expressava-se, assim, o privilégio de uma ocupação que permite a criação livre de qualquer outra finalidade. Em outro anúncio, um cenógrafo de 25 anos sintetizava: "felicidade é não ter tempo para ser infeliz" (Veja, 02/08/00). Aqui se inverte o valor atribuído à falta de tempo, quando ocupado em um trabalho que é oportunidade de auto-expressão. A idéia de realização pelo trabalho encontra na arte alguma plausibilidade, como domínio onde o trabalhador ainda é criador. Ela é apresentada também como a possibilidade de "fazer a diferença", de afirmar o valor individual em um mundo de forças impessoais agigantadas. Pelo menos é o que afirmava o artista plástico, em outro anúncio: "Não quero passar pela vida sem um arranhão. Quero deixar a minha marca" (Veja, 06/09/00). Por fim, também o espírito gregário era celebrado nesta campanha de inspiração romântica: "Eu coleciono amigos. O resto é descartável", dizia o fotógrafo em outra peça publicitária (Veja, 25/10/00). Assim foi encerrada a participação de Free na grande mídia, uma vez que a publicidade de cigarros foi proibida no final daquele mesmo ano.

O uso da juventude como sinônimo de liberdade é muito presente também na publicidade de automóveis, especialmente, os modelos off-road. Nesses casos, o carro é um recurso para que se rompa com as amarras das necessidades cotidianas e, até mesmo, dos constrangimentos sociais. Em anúncio exemplar, a opção por um rally no deserto é assim justificada: "Minha mãe queria que eu tivesse aulas de piano. $\mathrm{O}$ meu pai queria que eu estudasse em Harvard. $\mathrm{O}$ meu professor queria que eu fosse advogado. A minha mulher quer que eu fique em casa. Por isso, aqui estou eu". O texto menor é uma verdadeira conclamação a autenticidade e liberdade pessoais: "Quando você vai fazer alguma coisa, as pessoas sempre esperam que você faça da forma que elas querem. E você acaba sempre fazendo. Mas, até quando o seu eu verdadeiro vai se deixar levar pela vontade dos outros? Os seus desejos não contam? Para responder à sua voz interior, a Mitsubishi criou veículos esportivos e de lazer como o espetacular Pajero. São máquinas criadas exclusivamente para impressionar a si mesmo. E a mais ninguém" (Veja, 03/01/96).

Em todos esses casos, a juventude é um recurso para ancorar os anúncios nos valores românticos da liberdade e da autenticidade pessoais, tendência que extrapola os ramos da produção voltados ao público jovem e alcança o conjunto da publicidade brasileira de ponta, ainda que, pela própria necessidade de diferenciação entre os concorrentes em cada mercado, as estratégias narrativas sejam forçadas a algum grau de diversificação. A abrangência do apelo à juventude deve-se ao fato de que é correlato a uma mudança no conjunto da publicidade brasileira, em que o fascínio pela industrialização antes manifesto na ênfase na "tecnologia" e no "prestígio", dentro dos anúncios, foi cedendo espaço para o 
Juventude, política e consumo: imagens juvenis na publicidade brasileira a partir de 1964

recurso à "qualidade de vida", de que a jovialidade, a liberdade e a autenticidade são ingredientes indispensáveis. Como indicativo da amplitude desse apelo, podemos tomar o caso de uma das marcas mais importantes do planeta, a Cocacola. A tendência começou a ser ensaiada nos produtos menos importantes da marca. Em 1989, um anúncio da Diet Coke mostrava um pai com um bebê na cama e sugeria: "voltar a ser criança. Busque esta sensação. E descubra o sabor de Diet Coke". O slogan explicitava à referência ao rejuvenescimento que, na cena, estava misturada ao tom emocional da relação entre pai e filho: "o sabor de viver em forma" (Veja, 25/01/89). A vida cheia de emoções aparece ainda mais nitidamente em anúncio posterior que dava, para a imagem de um casal numa praia ao pôr do sol, a seguinte legenda: "Hotel cinco estrelas numa versão Diet Coke". E conclamava os que pudessem resistir a esta nova versão do "luxo": "refresque suas idéias" (Veja, 04/01/95). Outro anúncio da mesma campanha descrevia, como "executivos em viagem de negócios", um grupo de surfistas divertindo-se numa praia. A tônica era a de atribuir o prazer a momentos descontraídos, por oposição à formalidade de um hotel de luxo ou de uma reunião de trabalho (Propaganda, $\mathrm{n}^{\circ}$ 506, out./94). Foi somente a partir de 2001 que a emoção prometida enveredou para a experiência de consumo da Coca-Cola comum e assumiu a forma de uma vida cuja qualidade repousa nos "momentos" vividos entre amigos e familiares. Na Veja, uma série de três cenas dava forma ao slogan: "gostoso é viver" (Veja, 02/05/01). Na primeira delas, um pai descia uma ladeira no skate do filho que o observava. Na seguinte, jovens riam em um bar casual, todos com uma Coca-Cola na mão. A presença indispensável do refrigerante nos "momentos felizes" é reforçada na última cena, em que uma criança retira uma Coca-Cola da prateleira de um supermercado. Deste modo é diluída a oposição entre o cotidiano da rotina e o dos momentos extraordinários, sendo o produto e sua onipresença a garantia de prazer, alegria e felicidade intensamente associados, senão à juventude como faixa etária, pelo menos, a uma atitude juvenil de descontração, informalidade, paixão, liberdade e autenticidade.

Todos esses anúncios são indicativos da forte presença de uma matriz romântica na publicidade, assimilada por publicitários e pelos anúncios, em que o jovem encarna uma promessa de felicidade e um desejo de mudança hoje perfeitamente integrados à sociedade capitalista. $\mathrm{O}$ jovem, que na sociologia costuma ser tratado a partir do problema da ordem e da socialização, desde o romantismo teve a sua condição social instável ressignificada em termos muitos positivos, tornando-se supostamente o portador da vontade de transformação social e último reduto da resistência ao "reino das forças econômicas frias e impessoais". Como mostrou Campbell, a ética romântica convergiu para a justificação moral do consumo e assim se integrou aquele mesmo reino a que se opunha inicialmente. Aqui, mostramos que não somente romantismo e consumo são convergentes, como também, em um plano bem mais específico, a concepção romântica de juventude é a matriz de muitos anúncios da publicidade brasileira desde a década de 1960. Além disso, sugerimos que a imagem juvenil associada às marcas, nessa publicidade, pode ser explicada, em parte, como a projeção diluída dos ímpetos contestadores de jovens artistas e intelectuais convertidos em profissionais de criação e pesquisa a serviço do mercado. Nas décadas de 1960 e 
1970, a racionalização da indústria da publicidade ainda não havia se completado e as "ilusões românticas" não haviam cedido ao pragmatismo instaurado a partir de 1980. Mas quando veio a crise econômica e os interesses imediatos dos anunciantes pesaram para valer na relação com as agências, esses ímpetos contestadores cederam diante da "lógica cultural do capitalismo tardio" (Jameson, 1996). Parafraseando Perry Anderson, é como se, na publicidade, as utopias fossem como lindos fogos de artíficio, que enchem o céu de luz e cor mas, ao final, nos deixam com "esta" história. (Anderson, 1999) 
Juventude, política e consumo: imagens juvenis na publicidade brasileira a partir de 1964

\section{Bibliografia}

ABRAMO, Helena. "Considerações sobre a tematização da juventude no Brasil”. In Revista Brasileira de Educação. oํ 5, mai./ago., 1997.

ANDERSON, Perry. As origens da pós-modernidade. Rio de Janeiro: Jorge Zahar ed., 1999.

CAMPBELL, Colin. The Romantic Ethic and the Spirit of Modern Consumerism. Oxford: Basil Blackwell, 1987.

DURAND, José Carlos. Educação e "Talento"no Mundo da Publicidade. Mimeo, s.d..

FICO, Carlos. Reinventando o Otimismo - Ditadura, Propaganda e Imaginário Social no Brasil. Rio de Janeiro: Editora Fundação Getúlio Vargas, 1997.

FIGUEIREDO, Anna Cristina Camargo Moraes. Liberdade é uma Calça Velha, Azul e Desbotada - Publicidade, Cultura de Consumo e Comportamento Político no Brasil (1954-1964). São Paulo: Hucitec, 1998.

KLEIN, Naomi. Sem Logo - a Tirania das Marcas em um Planeta Vendido. Rio de Janeiro: Record, 2002.

JAMESON, Fredric. Pós-modernismo - A Lógica Cultural do Capitalismo Tardio. São Paulo: Ática, 1996.

ORTIZ, Renato. A moderna tradição brasileira - cultura brasileira e indústria cultural. São Paulo: Brasiliense, 1988.

RAMOS, José Mário Ortiz. Cinema, Televisão e Publicidade: o Audiovisual e a Ficção de Massa no Brasil. Tese de Doutoramento, PUC-SP, 1990.

ROCHA, Maria Eduarda da Mota. A nova retórica do capital - a publicidade brasileira em tempos neoliberais. São Paulo: Edusp, 2010.

SIVULKA, Juliann. Soap, Sex, and Cigarettes - a Cultural History of American Advertising. Nova Iorque: Wadsworth ed., 1998.

TASCHNER, Gisela. Proteção do Consumidor: um Estudo Comparativo Internacional. Mimeo, s.d.

Periódicos citados:

Propaganda, $\mathrm{n}^{\circ} 207$, out./73.

Propaganda, $\mathrm{n}^{\circ} 149$, out./68.

Propaganda, n० 506, out./94.

Anuário de Propaganda, 1971.

Veja, 20/06/84. 
Veja, 11/05/88.

Veja $04 / 11 / 87$.

Veja, 19/08/87.

Veja, 20/03/85.

Veja, 23/09/87.

Veja, 13/02/80.

Veja, 19/10/83.

Veja, 10/03/82.

Veja, 12/04/89.

Veja, 12/04/89.

Veja, 30/05/84.

Veja, 27/06/84.

Veja, 30/01/85.

Veja, 15/01/97.

Veja, 28/02/96.

Veja, 24/03/99.

Veja, 26/07/00.

Veja, 02/08/00.

Veja, 06/09/00.

Veja, 25/10/00.

Veja, 03/01/96.

Veja, 25/01/89.

Veja, 04/01/95.

Veja, 02/05/01. 